\title{
THE RIFT: A NEW AFRICA BREAKS FREE
}

URITTEN BY ALEX PERRY.

UEIDENFELD \& NICOLSON, LONDON, 2015. P. 431.

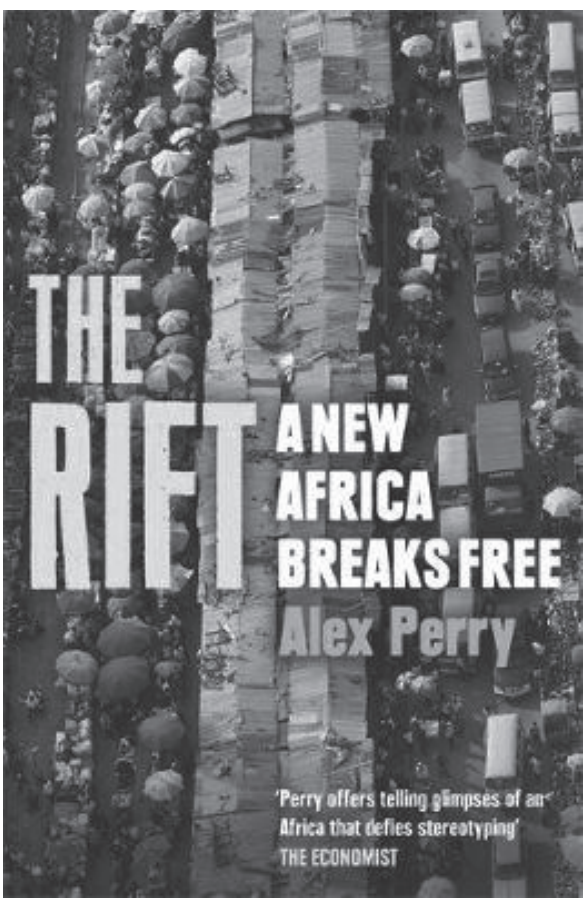

REVIEU BY: SZABOLCS PÁSZTOR

ASSOCIATE PROFESSOR, NATIONAL UNIVERSITY OF PUBLIC SERVICE, HUNGARY

PASZTOR.SZABOLCS@UNI-NKE.HU

Pásztor, Szabolcs (2020). The Rift: A New Africa Breaks Free. Review. Hungarian Journal of African Studies [Afrika Tanulmányok], 14(6), 88-90. 
Recently, we have seen an increasing number of books clustered around the issue of overturning Western perceptions of Africa, and in general the role of the West on the continent. By now, it is a well-known fact that Africa has long been misunderstood and abused by outsiders. The Rift written by Alex Perry tries to give an insider perspective and joins the list of books that give an introduction into what is going on behind the political, economic, and social curtains of the African countries.

Alex Perry is a correspondent and a frequent contributor to the Time and Newsweek. Also, he has authored the following books: Lifeblood, Failing off the Edge, Clooney's War, Cocaine Highway and Once Upon a Jihad. He has travelled Africa for a decade or so and met with locals: university professors, presidents, warlords, entrepreneurs, cocaine smugglers and ordinary people as well so he is very far from being an armchair expert only.

After reading the first sentences of the book, it turns out that the text is beautifully written and likely to spark intense academic debates as well. Alex Perry does not shy away from claiming at the very beginning that we have to follow the transforming African countries in order to revolutionise our ideas. In addition, we have to remind ourselves to get rid of the century-old misconceptions.

The Rift is separated into three different parts and the chapters contain countryrelated stories. These fourteen pieces are like mosaics: when we put them together we can indeed get a nuanced picture of contemporary Africa. The extraordinary stories show how a billion of Africans are struggling with charities and NGOs, jihadists, despots, and their freedom. Basically, Alex Perry starts his continental journey in Somalia during the catastrophic 2011 famine, then, jumps to the world's newest and most volatile nation, South Sudan and shows us 14 more Sub-Saharan African countries. From the very beginning, he is trying to place the current crises into historical context and seasons them with on-the-ground stories. Among the mosaics we can find pieces of famine, AIDS, humanitarian aid, terrorism, corruption, and the Chinese influence, as well. The chapters are perfect supplements for those who can rarely visit these African countries and/or do research without taking into consideration the historical, political and local perspectives. In this light, the reader may feel that the book is a bit far from the heavy-weight scientific argumentation but later we immediately realise that the context given by the author is much needed for having a better understanding of how the African countries are undergoing changes.

First of all, the reviewer has to highlight that as much as Alex Perry is good at giving a snapshot of the rapidly changing Africa, he proves to be weak in finding out and presenting why Westerners still maintain the deep-rooted perceptions on the continent and how the unprecedented changes fit into the long history of the regions, countries. In this way, I argue that a broader historical perspective is missing and it would have been better to use the longue durée approach instead of being impressed by the groundbreaking changes. We know very well that we have always been influenced by the latest political, social and economic movements, still we have to place the most recent changes in long historical perspectives. Also, I need to underline that the book contains a Further reading section which is full of vivid and meticulously selected pieces on 
Africa. Even any 'heavy-weight economist' dealing with econometric analyses can find many supplementary materials if they want to avoid the critical questions related to the real African context. Among the listed books we can find those authors who can bridge the historical context and the current changes happening on the surface.

Alex Perry has been a well-known contributing editor and his way of thinking and his writings are definitely not influenced by strict scientific argumentation, theoretical frameworks and long academic discussions. Instead, his main building blocks are observed facts, on-the-ground stories, real faces and voices. After reading the book it becomes clear that the author does not intend to join the long list of scholars doing research on Africa, instead he tries to colour the general picture on Africa. Bearing this in mind, he may receive criticism from the academic echelons and some may find his conclusions pointless, baseless and less clear. However, labelling the book belowstandards would confuse those academics who attach a greater importance to firsthand experience and real-life situations. Not trying to decide about who may be right, I can claim that the book represents its own class: a bridge between the theoretical and everyday Africa.

In sum, we can point at the message of the book, that Africa cannot be reduced to unending conflicts, tyrannical despots, war crimes and extreme poverty only. The continent has been a growing and innovative part of our planet capable of formulating developing strategies and technologies to deal with challenges. Even the Westerners can borrow this inspiration in many ways. The book may offer a better context for Africa's current condition than a number of books written on the continent so far.
Among the mosaics we can find pieces of famine, AIDS, humanitarian aid, terrorism, corruption, and the Chinese influence, as well.

The chapters are perfect supplements for those who can rarely visit these African countries and/or do research without taking into consideration the historical, political and local perspectives. In this light, the reader may feel that the book is a bit far from the heavyweight scientific argumentation but later we immediately realise that the context given by the author is much needed for having a better understanding of how the African countries are undergoing changes. 